\title{
伝統的木造住宅の維持管理における工務店による共助に関する考察
}

\author{
工務店を対象としたアンケート調査より

\section{A STUDY ON COOPERATION OF BUILDING CONTRACTORS IN THE MAINTENANCE OF TRADITIONAL WOODEN HOUSES}

Based on a questionnaire survey among building contractors

\author{
藤平 眞紀子* \\ Makiko FUJIHIRA
}

\begin{abstract}
This study examined both potential and ideal approaches for cooperation of building contractors in the maintenance of traditional wooden houses. We conducted a questionnaire survey on traditional wooden houses and streetscape preservation among contractors engaged in building and carpentry within Nara Prefecture.

As a result, there is widespread acceptance that traditional wood-frame houses with their traditional character must be preserved in order to maintain harmony with local landscapes, but also that these houses need to meet the requirements of the house occupants. Specifically, these efforts need to be pursued as collaborative initiatives between the occupants, local residents, specialists, and various tradesmen, with an emphasis on the quality of life of the house occupants. The survey also clearly showed that building contractors recognize that they need to collaborate in the maintenance of traditional wooden houses and also that they are willing to be involved in the effort.
\end{abstract}

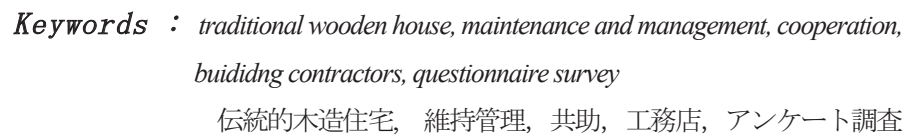

1. はじめに

築年数を経た伝統的な木造住宅が、老朽化や耐震性への不安、現 在の生活スタイルに合わないなどの理由から、取り壊されたり、新 しいタイプの住宅に建て替えられたりしてきている。個々の住宅は 多くの場合、個人の所有物であり、日頃の手入れや補修、改修、建 て替えなどの維持管理は所有者に任されている。一方、住宅が建ち 並び、集まって存在することにより、町並みや町が形成されており、 個々の住宅は地域環境に影響をおよぼす社会財としても位置づけら れる。明治時代以降、商業などの発達により、町家が建ち並び、趣 のある町並みを形成している地域も多いが、伝統的建造物や文化財 等の指定を受けていない住宅は、居住者の高齢化や居住者不在など から適切な維持管理が行われにくくなり、老朽化の進行や安全性の 低下、またそれらに伴う地域環境への影響などが危惧されている。 一方、そのような伝統的木造住宅やそれらによって形成される町並 みを、維持・保全していこうとする活動もみられる。

木造住宅（伝統工法、在来工法を含む）の維持管理について、居 住者の維持管理意識や管理行為の実践が住宅の損傷や耐久性に影響 していることが明らかにされている1，2，3，4）。また、居住者は住 宅の維持保全工事を地域の専門工事業者に依頼する傾向が強く ${ }^{5)}$ 、
戸建て木造住宅の維持管理においてつくり手の役割が期待され、そ れをサポートする仕組み・体制の整備が求められている ${ }^{6)}$ 。らに、 住宅管理の社会的支援のあり方についても論じられている ${ }^{7)}$ 。近年 では、地域工務店による木造住宅のメンテナンスサービスに求めら れる要件が考察されている ${ }^{8)}$ 。このように、住宅の維持管理におい て、居住者を主体として、居住者の維持管理行為を等ポートするつ くり手が関わり、その相互作用（共助）が重要であるといえる。

また、伝統的木造住宅の維持管理に関寸る居住者へのヒアリング 調查から住み手と大工や職人との良好な関係が住宅の維持管理にお いて重要であることが明らかになっている ${ }^{9)}$ 。また、伝統的木造住 宅の維持管理において、居住者と大工や職人が相互に関わり合う維 持管理システムが大きな役割を果たしていたと考えられている ${ }^{10)}$ 。 さらに、伝統的な木造住宅の維持管理において、「出入りの大工」の 存在が大きかったと言われている ${ }^{11)}$ 。そして、居住者と大工・職人 の関係について、既に以下のような報告がある。橋本らは、京都市 都心部における伝統的木造建物の維持管理の仕組みに着目し、既存 のストックを有効に活用していく実際的な方法として、維持管理の システムの重要性は大きく、地域にあった維持管理システムを現代

* 奈良女子大学研究院生活環境科学系 准教授・博士 $($ 学術 $)$

Assoc. Prof., Nara Women’s University, Ph.D. 
的に再構築寸ることが重要であると述べている ${ }^{12)}$ 。また、長谷川は、 歴史的市街地において長年にわたり町家の存続を可能としてきたの は、居住者の住要求に適切に対処することができた大工職人に負う ところが大きく、町家の維持管理に大きな役割を果たしてきたこと を報告している ${ }^{13)}$ 。さらに水野は、金沢市中心部における町家に住 む家族類型の変化（内的な要因）と技術的に支援寸る出入りの大工 との関係性の変化（外的な要因）双方の関係からの検討を行い、出 入りの大工が居住世帯との付き合いを続けて、町家の価值を語り続 けていることで彼らの歴史的認識などを高め、結果として居住継続 意向の強化に繋がっていることを明らかにしている ${ }^{14)}$ 。のように、 大工・職人は居住者との関わりから、伝統的木造住宅の維持管理に 深く関わっており、従来は一対一の関係であった。しかし、居住者 の高齢化や家族人数の減少、空き家の問題などから維持管理のシス テムの重要性が論じられるようになり、個々の関係だけではなく、 地域の大工・職人と地域の住民、地域の木造住宅という関係になり つつあると考えられる。そして、維持管理システムのあり方として、 自助のみでなく、共助、公助の連携による維持管理システムが強く 求められてきていると考えられる。

そこで、伝統的な木造住宅がその地域で、町並みを形成する地域 資源としても継承されていくためには、所有者による管理だけでは なく、地域の人々や専門的技術を有する各種職人、さらには公的な サポートなどの協同が必要であると考えられる。自助のみでなく、 共助、公助による伝統的木造住宅の維持管理の可能性やあり方を探 ることを本研究の目的としている。本報告では、住宅のつくり手、 つまり建設業や大工業に関わっている業者（以降、工務店と記寸） を対象として、住宅のハード面から管理に関わる立場の専門家とし て、また、居住者による維持管理を支える専門家として、伝統的木 造住宅の維持管理における共助の可能性、共助のあり方を検討した。

\section{2. 研究の方法}

調查対象は、国土交通大臣の許可を受けた業者のうち奈良県に本 店のある建設業者、および奈良県知事の許可を受けた建設業者の名 簿から、建築一式工事業および大工工事業または左官工事業を許可 されている業者 496 社を選定した。アンケートは 2014 年 1 月に依頼 状とともに郵送で配布し、郵送で回収した。64 社より有効回答を得 た。なお、アンケート調查を実施するにあたり、用語を以下のよう に定義した。維持管理、空き家について、括弧内の定義を参考にし た。

・伝統的木造住宅 : 木組みの軸組構法で、壁が左官仕上げである 住宅

・維持管理 : 現在の状態を保ち劣化を防ぐために、清掃、点検、 補修などを日常的、定期的に行うこと（建築・設備および諸施 設等の性能または機能を常時適切な状態に維持する目的で行 う維持保全の諸活動ならびにその関連業務を効果的に実施す るために施す管理活動 ${ }^{15)}$ )

・継承：今までの状態を受け継ぐこと

・空き家：人が住んでいない住宅、モノが置いてある場合もある (ふだん人が居住していない住宅 ${ }^{16)}$ )

\section{3、結果および考察}

\section{（1）回答工務店および回答者の概要}

表 1 に回答工務店の概要を示す。工務店の創業年は 1911 年から 2010 年であった。従業員数は 1 4 45 人であり、平均 10.7 人であっ た。創業年と従業員数の平均をみると、創業の古い工務店で従業員 数が多い傾向がみられ、明治・大正期創業では平均 15.9 人、昭和戦 後（昭和戦後 I 期および II 期）創業では平均 10.3 人、平成以降創 業では平均 8.2 人であった。また、大工や専門職との連携について (表 2)、回答工務店の 8 割以上は大工や専門職との連携をとりなが ら業を行っている。

表 3 に回答者の概要を示すように、性別は男性 93.7\%、女性 6.3\% であり、男性からの回答が多数を占めている。年齢は 30 82 歳であ り、平均 56.1 歳であった。また、就労年数は 2 61 年であり、平均 31.2 年であった。就労年数 30 年以上が 6 割を占め、経験豊かな回 答者が多いといえる。

\section{表 1 回答工務店概要}

\begin{tabular}{|c|c|c|c|c|}
\hline 創業年 & $\%(n=64)$ & 従業員数の平均(人) & 従業員数 & $\%(n=64)$ \\
\hline 明治·大正（1926年以前） & 10.9 & 15.9 & 1〜4人 & 48.4 \\
\hline 昭和戦前（1927～1945年） & 0.0 & - & 5〜9人 & 18.8 \\
\hline 昭和戦後|期（1946～1969年） & 32.8 & 12.0 & 10〜19人 & 14.1 \\
\hline 昭和戦後||期（1970～1989年） & 32.8 & 8.0 & 20人以上 & 15.6 \\
\hline 平成（1990年以降） & 17.2 & 8.2 & & \\
\hline
\end{tabular}

\section{表 2 大エや専門職との連携}

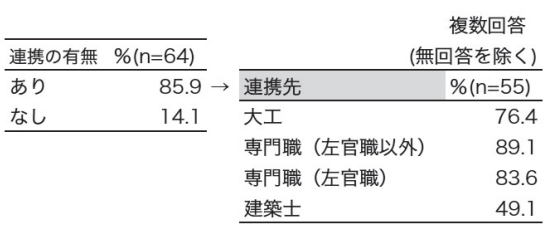

\section{表 3 回答者概要}

\begin{tabular}{|c|c|c|c|c|c|}
\hline 性別 & $\%(n=64)$ & 年齢 & $\% \quad(n=64)$ & 就労年数 & $\%(n=64)$ \\
\hline 男性 & 93.8 & 40歳未満 & 15.6 & 10年未満 & 6.3 \\
\hline \multirow[t]{3}{*}{ 女性 } & 6.3 & $40 \sim 60$ 歳 & 42.2 & 10 30年 & 29.7 \\
\hline & & 60歳以上 & 42.2 & $30 \sim 50$ 年 & 50.0 \\
\hline & & & & 50年以上 & 10.9 \\
\hline
\end{tabular}

\section{（2）住宅の維持管理に関する業としての日頃の活動}

住宅の維持管理に関寸る情報発信や相談受け付けを日頃の維持管 理に関する活動として、工務店の業務としての実施状況をみると、 活動「あり」と「なし」はほぼ半々であった（表 4)。住宅の維持管 理に関する日頃の活動が活発なのは、創業が明治・大正期もしくは 平成期の工務店であり、従業員数は $5 \sim 9$ 人または 20 人以上であっ た。維持管理に関して、ある程度の従業員数、役割分担が必要であ ると考えられる。活動「あり」について、情報発信や相談受け付け の時期は 2008 年以前が多い。2008 年に施行された長期優良住宅の 普及の促進に関する法律では、維持保全計画の策定が求められてお り、同法に伴い、工務店としても維持管理への関心や認識が高まっ ていると予想したものの、回答工務店において同法の影響は少ない と思われる。創業年の古い工務店が多かったこともあり、以前から 維持管理に関する日頃の活動が行われていたと考えられる。具体的 
表 4 住宅の維持管理に関する情報発信や相談受け付けの実施状況

\begin{tabular}{|c|c|c|c|}
\hline 情報寻 & $\%(\mathrm{n}=64)$ & & \\
\hline あり & 51.6 & 創業年 & $\%(n=64)$ \\
\hline なし & 48.4 & 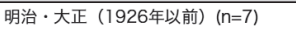 & 71.4 \\
\hline & & 昭和戦後|（1946～1969年）(n=21） & 42.9 \\
\hline & & 昭和戦後II（1970 1989年）( $n=21)$ & 42.9 \\
\hline & & 平成（1990年以降）(n=11) & 63.6 \\
\hline & & 従業員数 & $\%(n=64)$ \\
\hline & & 1〜4人(n=31) & 48.4 \\
\hline & & $5 \sim 9 人(n=12)$ & 58.3 \\
\hline & & 10 19人(n=9) & 33.3 \\
\hline & & 20人以上 $(n=10)$ & 70.0 \\
\hline & 情報発信や杭 & 炎受け付けあり $(n=33)$ & 回答数 \\
\hline & 開始時期 & 2008年以前 & 20 \\
\hline & & 2009年以降 & 4 \\
\hline & 具体的内容 & 定期的メンテナンス & 9 \\
\hline & & 相談宏口設置 & 5 \\
\hline & & 老人宅対応 & 2 \\
\hline & & 屋根点検 & 2 \\
\hline & & 金属部点検、木部点検、地盤沈下点検 & 各1 \\
\hline & & 耐震改修、部分補修 & 各 1 \\
\hline & 情報発信や林 & 炎受け付けなし $(n=31)$ & 回答数 \\
\hline & 理由 & 依頼がない & 6 \\
\hline & & 時間·人手不足 & 5 \\
\hline & & 主業務外 & 9 \\
\hline & & 必要ない·自信あり & 3 \\
\hline
\end{tabular}

には、定期的メンテナンスであり、定期的に点検を行っている。ま た、相談空口を設置して、居住者からの相談を受け付けしやすくす る工夫も行われている。一方、維持管理に関する活動をしていない 工務店において、その理由は内装工事を主としている、依頼がない、 時間・人手不足であった。従業員の少ない工務店では、維持管理に 関寸る活動は人手不足のため取り組めていない実態がわかった。な お、依頼がないという回答は、創業年の浅い工務店が多く、依頼が ないから関わる機会がなく、現在のところ具体的な活動に至ってい ない。しかし、居住者からの要望があれば対応する姿勢はみられ、 今後、情報発信や相談受け付けを行っていく可能性はあると期待さ れる。

\section{（3）伝統的木造住宅の建物調査}

伝統的な木造住宅を維持管理していく上で、建物状態を把握する ことは重要である。そこで、伝統的木造住宅の建物調査について業 としての経験の有無をみると（表 5)、建物調査「あり」31.3\%、「な し」 $67.2 \%$ であった。「なしが多かったのは、建物調查の依頼が少 なかったためと予想され、住み手（所有者）が建物調査の必要性を 有していない現状が伺える。建物調查「あり」の回答数は少なかっ たものの、回答工務店において創業年の古い工務店や従業員数の多 い工務店で建物調査が実施されている割合が高い傾向がみられ、住 宅に関わってきた経験と建物調查に携わる専門家との関わりが影響 していると予想される。

\section{表 5 伝統的木造住宅の建物調査の実態}

\begin{tabular}{|c|c|c|}
\hline & あり(\%) & なし(\%) \\
\hline 建物調査実施の有無 $(n=64)$ & 31.3 & 67.2 \\
\hline 創業年 & あり(\%) & なし(\%) \\
\hline 明治·大正（1926年以前） $(n=6)$ & 66.7 & 33.3 \\
\hline 昭和戦後|（1946～1969年）( $n=21)$ & 33.3 & 66.7 \\
\hline 昭和戦後II（1970～1989年） $(n=21)$ & 23.8 & 76.2 \\
\hline 平成（1990年以降） $(n=11)$ & 27.3 & 72.7 \\
\hline 従業員数 & あり(\%) & なし(\%) \\
\hline 1 4人 $(n=30)$ & 30.0 & 70.0 \\
\hline $5 \sim 9$ 人 $(n=12)$ & 41.7 & 58.3 \\
\hline 10 19人 $(n=9)$ & 11.1 & 88.9 \\
\hline 20人以上 $(n=10)$ & 50.0 & 50.0 \\
\hline
\end{tabular}

建物調查「あり」について、代表的な事例について詳細に尋ねた。 27 事例が挙げられ、その概要を表 6 に示す。建物調查を行った時期 は 1984 2013 年であり、1 事例以外は 2000 年以降の比較的新しい 事例であった。場所は奈良県内が 16 例と半数以上を占め、それ以外 は近隣府県であった。建物調查を行った理由は、家主からの依頼が 多く、改修工事を進めるためであった。なお、地域住民、地元 NP0 からの依頼は 1 例ずつあり、わずかではあるものの、第三者からの 依頼もあることがわかった。主な調查内容は耐震調查が 6 例、劣化 調查が 21 例であり、建物および部材の傷みの程度を知る、確認する ことが主になっている。部材の劣化診断は多く行われており、目視 で実施されていることが多く、機器を用いた例は 1 例のみであった。 部材の劣化診断の点検䇢所は床下や土台、柱や梁の構造材が多く、 腐朽や蟻害の有無や程度が調べられている。また、雨漏りが気にな る場合は、屋根や外壁の点検が強調されていた。建物調查を実施す る際に問題があったと 8 割以上の事例で回答されており、具体的に は「費用がかかる」、「担当できる人が限られている」、「時間不足」、 「荷物が多い」であり、家主（施主）にとって負担となる費用面、 実施する側にとって課題となる担当者不足の問題が挙げられた。ま た、建物調查に関寸る課題として、「調査項目が明確になっていない」 「記録の残し方にルールがない」、「過去の記録がない」、「担当者の 判断に大きく影響する」、「無償で行わざるを得ない場合がある」な どが具体的に挙げられた。今までの経験に基づいた方法だけでなく、 調査項目や診断方法、診断結果の判定においてある程度のルール化 が必要であり、担当できる次の世代を育てていくためにも、建物調 查の項目の整理や診断方法の整備が必要だと考えられていることが 明らかとなった。

建物調查への今後の取り組みについて（表 7)、建物調查経験あり では、「取り組んでいきたい」と考えられている割合が高い。自分の 仕事である、やりがいがあるためである。一方で、施主の考え方に よる、施主との信頼関係がなければ難しいという意見もあった。取 り組みたくない理由は、マニュアル化できていないためであった。 また、建物調查経験なしでは、「取り組みたくない」と考えている工 務店は半数以上を占め、消極的な様子が伺える。取り組みたくない 理由は、「技術・知識不足」、「時間・人手不足」であり、現状ではこ れらを補う余力がないようである。一方、取り組んでみたいと考え

\section{表 6 伝統的木造住宅の建物調査 27 事例の概要}

\begin{tabular}{|c|c|c|c|c|c|}
\hline & & 答数 & $=27)$ & & \\
\hline \multirow{4}{*}{$\begin{array}{l}\text { 実施理由 } \\
\text { (複数回答) }\end{array}$} & 家主からの依頼 & 17 & 63.0 & & \\
\hline & 地域住民からの要望 & 2 & 7.4 & & \\
\hline & 改修工事をするため & 14 & 51.9 & & \\
\hline & その他 & 3 & 11.1 & & \\
\hline \multirow[t]{2}{*}{ 具体的内容 } & 耐震調査 & 6 & 22.2 & & \\
\hline & 劣化調査 & 21 & 77.8 & & (複数回答) \\
\hline \multirow[t]{5}{*}{ 部材の劣化診断 } & 実施した & 24 & $88.9 \rightarrow$ & 点検箈所 & 回答数 \\
\hline & 実施していない & 3 & 11.1 & 床下·土台 & \\
\hline & & & & 柱等構造材 & \\
\hline & & & & 屋根 - 外壁 - 雨漏り & \\
\hline & & & & 建具·床 & \\
\hline \multirow{6}{*}{ 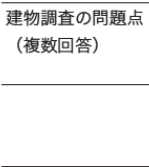 } & あり & 23 & $85.2 \rightarrow$ & 問題点 & 回答数 \\
\hline & なし & 0 & 0.0 & 荷物が多い & 3 \\
\hline & 無回答 & 4 & 14.8 & 時間不足 & 4 \\
\hline & & & & 担当者不足 & 9 \\
\hline & & & & 費用がかかる & 10 \\
\hline & & & & その他 & \\
\hline \multirow[t]{4}{*}{ 建物調査の課題 } & あり & 20 & $74.1 \rightarrow$ & 具体的な内容 & 回答数 \\
\hline & なし & 0 & 0.0 & 調査項目が明確でない & 12 \\
\hline & 無回答 & 7 & 25.9 & 記録の残し方にルールがない & , \\
\hline & & & & その他 & 5 \\
\hline
\end{tabular}


ている工務店では、比較的若い回答者が、自身の興味・勉強のため と理由を挙げていた。今までに関わる機会がなかったが、今後のた めに関わっていきたいと考えられていることがわかった。

このように、伝統的木造住宅の建物調查は、古い住宅の改修のた め、また改修の可能性を検討するために、目視により構造部材の劣 化の程度や雨漏りの状況、また建物の耐震性が調べられていること がわかった。建物調查において、費用がかかること、担当できる人 が限られていることが問題であり、今後、人材育成とともに調查項 目や記録の残し方を整備していくことが求められている。建物調査 にやりがいを感じている回答者は多いものの、施主との信頼関係が 最も重要であると感じており、施主（居住者）とのつながりが建物 の維持管理において重要であるといえる。

\section{表 7 伝統的木造住宅の建物調査への今後の希望}

\begin{tabular}{|c|c|c|c|}
\hline 建物調査経験あり & $\%(n=20)$ & & \\
\hline 取り組んでいきたい & 70.0 & & \\
\hline 取り組みたくない & 5.0 & & \\
\hline 無回答 & 25.0 & & \\
\hline 建物調直経験なし & $\%(n=43)$ & & \\
\hline 取り組んでみたい & 37.2 & ＼cjkstart取り組みたい理由 & $\%(n=16)$ \\
\hline 取り組みたくない & 55.8 & 自身の興味・勉強のため & 37.5 \\
\hline \multirow[t]{9}{*}{ 無回答 } & 7.0 & 技術継承のため & 18.8 \\
\hline & & 仕事に結びつくため & 18.8 \\
\hline & & 無回答 & 25.0 \\
\hline & & 取り組みたくない理由 & $\%(n=24)$ \\
\hline & & 時間‧人手不足 & 16.7 \\
\hline & & 技術·知識不足 & 25.0 \\
\hline & & 主業務外 & 8.3 \\
\hline & & 年齢的にしんどい & 4.2 \\
\hline & & 無回答 & 45.8 \\
\hline
\end{tabular}

\section{（4）伝統的木造住宅の改修工事}

伝統的木造住宅の改修工事について業としての経験の有無をみる と（表 8)、実施経験「あり」 $45.3 \%$ 、「なし」 $48.4 \%$ であった。創 業年の古い、従業員数 1 4 人または 20 人以上の工務店で改修工事 が行われている割合が高い。経験ありについて、今までの総戸数は 1〜150戸であり、数戸から 10 戸程度が多かった。具体的に 45 事例 が挙げられた。それらについてみると（表 9)、改修工事を行った時 期は 1987〜2013 年であり、2000 年以降が約 7 割を占めている。県 内の事例が 6 割以上を占め、それ以外は近畿圈内である。伝統的建 造物群保存地区の指定を受けている地区での例は 9 例あった。建物 の築後年数は $20 \sim 193$ 年であり、平均 100.9 年であった。居住宅が 多いものの、居住していない住宅の改修も6 例含まれていた。この 6 例について、居住用に改修が 2 例、倉庫用に改修が 2 例、作業所 用、観光施設用に改修が各 1 例であった。4 5 事例の改修工事の内容 をみると、耐震補強は 26 例あり、筋かいを金物で補強するが多く、 傷んだ柱材の脚部を交換した例もあった。断熱補強は 24 例あり、床

\section{表 8 伝統的木造住宅の改修工事の実施状況}

\begin{tabular}{|c|c|c|}
\hline & あり(\%) & なし(\%) \\
\hline 改修工事実施の有無(n=64) & 45.3 & 48.4 \\
\hline 創業年 & あり(\%) & なし(\%) \\
\hline 明治·大正（1926年以前）(n=6) & 66.7 & 33.3 \\
\hline 昭和戦後|（1946 1969年）(n=21) & 52.4 & 47.6 \\
\hline 昭和戦後||（1970～1989年）（n=21） & 45.0 & 55.0 \\
\hline 平成（1990年以降）(n=11) & 40.0 & 60.0 \\
\hline 従業員数 & あり(\%) & なし(\%) \\
\hline $1 \sim 4$ 人 $(n=30)$ & 53.3 & 40.0 \\
\hline 5 9人 $(n=12)$ & 41.7 & 58.3 \\
\hline $10 \sim 19 人(n=8)$ & 25.0 & 75.0 \\
\hline 20人以上 $(n=10)$ & 50.0 & 50.0 \\
\hline
\end{tabular}

\section{表 9 伝統的木造住宅の改修工事 45 事例の概要}

\begin{tabular}{llrr}
\hline & & 回答数 $\%(\mathrm{n}=45)$ \\
\hline 改修工事住宅の & 伝建地区 & 9 & 20.0 \\
所在地 & 伝建地区以外 & 36 & 80.0 \\
\hline 築後年数 & 築後50年未満 & 4 & 8.9 \\
& 築後50 100年 & 10 & 22.2 \\
& 築後100 150年 & 11 & 24.4 \\
& 築後150年以上 & 7 & 15.6 \\
& 不明 & 13 & 28.9 \\
\hline 居住の有無 & 居住あり & 30 & 66.7 \\
& 居住なし & 6 & 13.3 \\
\hline 改修工事内容 & 耐震補強 & 26 & 57.8 \\
& 断熱祼強 & 24 & 53.3 \\
& シロアリ駆除 & 27 & 60.0 \\
& 屋根改修 & 28 & 62.2 \\
& 外壁改修 & 32 & 71.1 \\
& 内壁改修 & 35 & 77.8 \\
& 設備改修 & 33 & 73.3 \\
& 床下環境整備 & 17 & 37.8 \\
\hline 改修工事の問題 あり & 19 & 42.2 \\
& なし & 20 & 44.4 \\
\hline
\end{tabular}

下や天井に断熱材を挿入して対応している。シロアリ駆除は 27 例あ り、床下への薬剤散布が 26 例、土台に防腐・防蟻薬剤注入材の使用 が 1 例であった。屋根改修については 28 例あり、瓦の莫き替えが 12 例と多く、下地改修も 3 例あった。また、莫き材の変更もみられ た。外壁改修は 32 例あり、漆喰の塗り替え（9 例）、壁の仕様変更 （6 例）が多い。内壁改修は 35 例あり、塗り壁の塗り直し（11 例）、 クロスの張替え、下地の補修、仕様変更が行われている。設備改修 は3 33 例あり、電気・設備機器の整備が多く（7 例）、台所、風呂、 トイレの水回りで現代様式に変更されている。床下環境整備は 17 例あり、ベタ基礎や防湿コンクリートへの変更が多く（7 例）、土壌 の入れ替えは 2 例あった。

次に、改修工事内容ごとに改修工事住宅の築後年数別の実施率を みると（表 10）、屋根改修および外壁改修は築後年数が経るにつれ 実施率が高くなっている。また、シロアリ駆除および床下環境整備 は築後 100 年前後の住宅で実施率が高い。内壁改修や設備改修は築 後年数の浅い住宅でも実施されている。また、床下や屋根の断熱性 を高める断熱補強は築後 50 年未満の比較的新しい住宅で実施率が 高い。このように、築年数が 50 年程度であると住宅内部で、築年数 が経るにつれてシロアリ駆除、屋根や外壁の改修といった、住宅の 外部、建物の耐久性に大きく影響する部位の改修が増加している。 生活者の生活のしや寸さや快適性を求める改修から、それらに加え て建物や部材の傷みの程度に合わせた改修が適宜行われてきている と考えられる。

なお、改修工事を行うにあたって、トラブルも発生しており、工 事内容別では、屋根改修、外壁改修、耐震補強および内壁改修で発

\section{表 10 伝統的木造住宅の工事内容別にみた改修工事住宅の築後 年数別実施率と改修工事におけるトラブル発生率}

\begin{tabular}{|c|c|c|c|c|c|}
\hline & 改修工事実施率 ( & & & & 改修工事の問題 \\
\hline 改修工事内容 & $\begin{array}{c}\text { 築後50年未満 } \\
(\mathrm{n}=4)\end{array}$ & $\begin{array}{c}\text { 築後50 100年 } \\
(\mathrm{n}=10)\end{array}$ & $\begin{array}{c}\text { 築後100 150年 } \\
(n=11)\end{array}$ & $\begin{array}{c}\text { 築後 } 150 \text { 年以上 } \\
(n=7)\end{array}$ & $\begin{array}{l}\text { 発生率(\%) } \\
\quad(n=45)\end{array}$ \\
\hline 耐震補強 & 50.0 & 70.0 & 63.6 & 57.1 & 28.9 \\
\hline 断熱補強 & 100.0 & 70.0 & 54.5 & 42.9 & 20.0 \\
\hline シロアリ駆除 & 50.0 & 70.0 & 90.9 & 57.1 & 24.4 \\
\hline 屋根改修 & 50.0 & 60.0 & 54.5 & 85.7 & 31.1 \\
\hline 外壁改修 & 50.0 & 80.0 & 81.8 & 85.7 & 28.9 \\
\hline 内壁改修 & 100.0 & 90.0 & 90.9 & 71.4 & 33.3 \\
\hline 設備改修 & 100.0 & 80.0 & 81.8 & 57.1 & 26.7 \\
\hline 床下環境整備 & 0.0 & 40.0 & 72.7 & 42.9 & 11.1 \\
\hline
\end{tabular}


生率がやや高い。具体的には、隣地との境界が不明、手抜き工事の 発覚により工事費用が増えた、道路が狭く作業しにくい、道路が一 方通行で作業しにくい、予想以上の傷みの発見、どこまで修理する か施主との話し合いが大変だった、費用がかかる割に効果が少ない と感じるなどが挙げられた。改修計画の際にはわからなかった不具 合や傷みに関連すること、また、住宅の立地状況に関することが多 く、予想できなかった内容、立地上やむを得ないことが起こってい る。

また、改修工事の経験のない工務店（n=31）において、今後、改 修工事に取り組みたい $38.7 \%$ 、取り組みたくない $48.4 \%$ であり、意 見が分かれた。取り組んでみたいと考えているのは、比較的若い回 答者、創業年数の浅い工務店であり、取り組みたい理由は技術の向 上や技術の継承のためであった。一方、取り組みたくない理由は、 時間・人手不足、技術・知識不足であり、また、今までの経験を活 かして取り組みたいものの体力的に不安を感じている回答者もいた。 以上のように、伝統的木造住宅の改修工事について、居住性や快 適性の確保とともに、耐震性などの安全性、また、傷んだ箇所の補 修による耐久性の確保がなされており、回答工務店の約半数はそれ らの工事に関わった経験を持っていることがわかった。今後、技術 の向上や技術の継承のために、伝統的木造住宅の改修工事に取り組 んでいきたいと考えられている一方で、規模の小さい工務店では時 間・人手不足、また、高齢の回答者では自身の体力的な不安から、 消極的な意見もみられた。伝統的木造住宅の改修工事を行っていく うえで、専門的な技術を持つ職人、専門家の連携が今まで以上に必 要になってくると考えられる。

\section{（5）伝統的な木造住宅を維持保全していくために必要なこと}

伝統的な木造住宅を維持保全していくために必要だと考えられ ることについて、技術面、材料面、制度面、経済面、発注・契約面、 居住者・住民の意識、地域の取り組みの各視点から記述式で回答を 得た。それらを整理すると、表 11 に示すように、技術面においては 回答数が多く、人材育成、技術の継承が強く求められており、加え て、これらを進めていくための環境整備も挙げられた。材料面につ いては、状況や場所による材料の使い分けや材料の質へのこだわり が強調され、一方で、材料不足や材料の質の低下への懸念が示され た。制度面においては、補助金制度の充実が求められており、居住 者への補助のみならず町並みへの補助、施工者への補助が必要であ ると考えられている。また、伝統的木造住宅の維持保全において、 現在の法規制への対応が難しく、状況に応じて法的な緩和も必要で あると考えられている。具体的に示された法規制は、景観に関する ことであった。さらに、技術面とも重なるところがあるが、各種職 人の技術の継承を支援する制度面の充実も挙げられた。経済面につ いては、資金不足が問題であり、居住者も各種職人も経済的に厳し い状況になると伝統的な木造住宅の維持保全が行われなくなると危 惧されている。発注・契約面においては、適切な見積もりのあり方、 施主との話し合い、そして施主との信頼関係が重要であることが強 調されている。居住者・住民の意識としては、居住者の維持管理意 識を高める、個々の住宅にとどまらず地域として伝統の継承意識を 高める、総合的に保全意識を持つことが重要だと考えられている。 地域の取り組みについては、協力体制の確立のために地域住民のつ

\section{表 11 伝統的木造住宅を維持保全していくために必要なこと}

\begin{tabular}{|c|c|}
\hline & （）内は回答数、複数回答 \\
\hline 視点 & 主な具体的内容 \\
\hline \multirow[t]{4}{*}{ 技術面(39) } & 人材育成(23) \\
\hline & 技術継承(15) \\
\hline & 技術者の置かれている環境整備(4) \\
\hline & その他(4) \\
\hline \multirow[t]{3}{*}{ 材料面(35) } & 材料へのこだわり(18) \\
\hline & 材料不足や材料の質の低下への対応(12) \\
\hline & その他(6) \\
\hline \multirow[t]{4}{*}{ 制度面(31) } & 居住者への補助金・施工者への補助金(14) \\
\hline & 法的緩和、法整備(10) \\
\hline & 技術継承のためのサポート体制(6) \\
\hline & その他(6) \\
\hline \multirow[t]{5}{*}{ 経済面(30) } & 資金不足(11) \\
\hline & 補助不足(9) \\
\hline & 利益が少ないことへの対応(6) \\
\hline & 管理にかける費用の低下(5) \\
\hline & その他(6) \\
\hline \multirow[t]{3}{*}{ 発注・契約面(22) } & 適正な見積もり、見積もりの難しさ(12) \\
\hline & 話し合いの重要性(7) \\
\hline & その他(6) \\
\hline \multirow[t]{4}{*}{ 居住者・住民の意識(32) } & 伝統の継承への意識を高める(21) \\
\hline & 居住者の維持管理意識を高める(5) \\
\hline & 町並みとしての保全意識(4) \\
\hline & その他(4) \\
\hline \multirow[t]{4}{*}{ 地域の取り組み(20) } & 地域・町並みへの配慮(10) \\
\hline & 地域の主体性(7) \\
\hline & 取組み対象をしぼる(7) \\
\hline & その他(3) \\
\hline
\end{tabular}

ながりが重要であり、意識の希薄化を心配する意見もみられた。ま た、改修工事の経験があると、特に技術面への回答が多く、人材育 成が急務である。加えて、居住者・住民の意識として、伝統の継承 一の意識を高める必要性を強く感じており、伝統的な木造住宅の維 持管理において、居住者の管理意識が重要であるとともに、居住者 の意識を支える専門家としての役割を認識していると考えられた。 なお、改修工事の経験がない工務店からの回答は全体に少なかった ものの、人材育成、技術継承、材料不足や材料の質の低下への対応 については気にかけていることがわかった。

このように、各視点からの意見をまとめると、伝統的な木造住宅 の維持保全において、人材、技術、材料、資金面での課題は多く、 社会の変化を受け入れつつ、サポート体制を整備していくことが必 要であることがわかった。また、個々の居住者の意識、個々の住宅 への工務店としての良質な木材やその他の材料、伝統的な技術や構 法などへのこだわりとともに、居住者と工務店のみならず、地域住 民を含めた協同やつながり、連携が求められているといえよう。

\section{（6）町並みの維持保全・継承への取り組み}

町並みの維持保全や継承への業としての取り組みについて（表 12)、取り組みありは 9 例と少なかった。取り組みありが少なかった のは、町並みの維持保全を考慮している地域の住み手（所有者）や 地域住民組織からの依頼が少なかったためと思われる。少ない事例 なので、内容が限定的になる可能性はあるものの、その詳細をみる と、そのほとんどは県内で行われている。取り組みのきっかけは、 改修工事の依頼とともに、住民組織からの依頼も 3 例あった。これ らの取り組みを通じての課題は、町や地域全体としての協力を得る こと、行政からの補助の必要性、住宅に関わる法的緩和であり、こ こでも地域住民との関わりが重要であることがわかる。今後の取り 


\section{表 12 町並みの維持保全・継承への取り組み}

\begin{tabular}{|c|c|c|c|}
\hline \multicolumn{4}{|c|}{ 町並みの維持保全・継承の取り組み 回答数 } \\
\hline 取り組みあり & 9 & & \\
\hline 取り組みなし & $46 \rightarrow$ & 今後の希望 & $\%(n=46)$ \\
\hline & & $\begin{array}{l}\text { 取り組んでみたい } \\
\text { 取り組みたくない }\end{array}$ & $\begin{array}{l}39.1 \\
54.3\end{array}$ \\
\hline
\end{tabular}

組みにも、肯定的な意見が半数以上を占め、町並みの維持保全や継 承一の熱い思いや自身の知識や技術を後輩に少しでも伝えたいと考 えられている。

一方、町並みの維持保全や継承への取り組みに関わったことがな い場合 $(\mathrm{n}=46)$ 、今後取り組みたい $39.1 \%$ 、今後取り組みたくない 54. 3\%であり、やや消極的な様子が伺えた。取り組みたい理由は、 伝統的な住宅や町並みが好き、これらを残したい、文化を継承して いきたいという思いであり、反対に取り組みたくない理由は人手不 足、時間不足、技術不足であった。これらのことから、現状で不足 していることが多く、そのために今後の取り組みに消極的にならざ るを得ない様子が伺える。技術不足については、技術の継承も含め て、講習会や勉強会などの開催も必要であろう。

町並みの維持保全や継承における手引書やガイドラインの必要性 について (表 13)、必要との意見は約半数を占めた。町並夕の維持 保全や継承一の取り組みの有無別にみると、取り組みありの方が手 引書やガイドラインを必要と強く感じている。居住者、地域住民、 町並み、施工者それぞれにとって必要であり、取り組みありの場合 は、「全員がその価值観を共有する必要がある」、「次世代一継承する ために必要」、「維持保全には皆の協力が必要」と考えられている。 一方、取り組みなしの場合は、居住者にとって必要との意見が目立 っていた。居住者重視の思いが強く、このことは重要であるものの、 全体を見渡し、バランスよく維持保全・継承していくことは経験的 に得られていくものであるように考えられた。町並みの維持保全や 継承における手引書やガイドラインは、これに関わる全ての人のた めに必要であり、皆の協力が町並みの維持保全や継承につながると いえる。

町並みの維持保全や継承において気をつけていること、気をつけ ていきたいこととして、デザイン・意匠、材料、色、寸法の視点か ら意見を得た。その結果を町並みの維持保全や継承の取り組みの有 無別にまとめて表 14 に示す。デザイン・意匠については、地域にな じむこと、調和・バランスがとれていることが意識されており、そ のためには行政による指導も必要との意見もみられた。材料につい ては、元の材料を活かす、質の良い材料、例えば木材であれば年輪 の詰まった通直な材などを用いることが意識されている。なお、「取

\section{表 13 町並みの維持保全・継承におけるガイドラインの必要性}

\begin{tabular}{|c|c|c|c|}
\hline $\begin{array}{l}\text { 手引書・ } \\
\text { ガイドラインについて }\end{array}$ & $\begin{array}{l}\text { 全体 } \\
\%(n=64)\end{array}$ & $\begin{array}{l}\text { 取り組みあり } \\
\%(n=9)\end{array}$ & $\begin{array}{l}\text { 取り組みなし } \\
\%(n=46)\end{array}$ \\
\hline 必要 & 48.4 & 77.8 & 52.2 \\
\hline 必要ない & 4.7 & 0.0 & 6.5 \\
\hline どちらともいえない & 17.2 & 11.1 & 21.7 \\
\hline 手引書・ガイドライン & & 取り組みあり & 取り組みなし \\
\hline & $\%(n=31)$ & $\%(n=7)$ & $\%(n=24)$ \\
\hline 居住者にとって必要 & 77.4 & 57.1 & 83.3 \\
\hline 地域住民にとって必要 & 38.7 & 57.1 & 33.3 \\
\hline 町並みにとって必要 & 54.8 & 57.1 & 54.2 \\
\hline 施工者にとって必要 & 38.7 & 57.1 & 33.3 \\
\hline
\end{tabular}

表 14 町並みの維持保全・継承について気をつけていること、 気をつけていきたいこと

\begin{tabular}{|c|c|c|}
\hline & 町並みの維持保全・継承の取り組みあり & 取り組みなし \\
\hline \multirow[t]{4}{*}{ デザイン・意匠 } & ·古いものを活かす & ・デザインを変えない \\
\hline & • 地域の建物の特徵を損なわないようにする & •地域の特徴を活かす \\
\hline & •軒先や屋根勾配など周囲と調和させる & ・環境との調和 \\
\hline & ·統一性にこだわらない & ・バランスを考える \\
\hline \multirow[t]{4}{*}{ 材料 } & ·自然のものを使う & ·自然のものを使う \\
\hline & ·現状のものを使う & ·現状のものを使う \\
\hline & ·伝統的な材料を使う & ·質の良いものを使う \\
\hline & $\begin{array}{l}\text { ·自然材を基本として、 } \\
\text { 新建材も限りなく自然材に近づけば使う }\end{array}$ & ·長持ちするものを使う \\
\hline \multirow[t]{3}{*}{ 色 } & ·現状重視 & ·素材の持つ色を活かす \\
\hline & ·限りなく自然色 & ·周囲になじむ色 \\
\hline & ·おしゃれな感じの色彩も必要 & ·自然の色 \\
\hline \multirow[t]{4}{*}{ 寸法 } & ·バランスの良い寸法 & ·使い勝手を重視する \\
\hline & ·現状に合わせる & ・現状に合わせる \\
\hline & ·用途に合わせる & ・人になじむ寸法 \\
\hline & •2階の階高が高すぎないようにバランスをとる & \\
\hline
\end{tabular}

り組みあり」において、基本は自然材であるものの、新建材への意 見もみられた。新建材を否定的に捉えるのではなく、自然材では対 応しきれない現状や新建材の多様化などから、自然材で対応できな い場合の代替品として考えられていると予想される。色については、 自然な色が心がけられており、現在の状況に応じた色が町並みにな じむと考えられている。また、「取り組みあり」において、おしゃれ な感じの色彩とあるように、現在の生活や若い人々に受け入れられ る工夫が求められていると予想される。寸法については、現状に合 わせる、元のバランスを崩さない、一方で、現代の寸法体系に変え ていくとの意見もみられ、取り組みの有無にかかわらず、考え方の 相違がみられた。

\section{（7）空き家の維持管理への取り組み}

空き家の維持管理への業としての取り組みは 9 事例あり (表 15)、 1985 年から 2011 年に県内で行われている。事例数が少ないことか ら、所有者が空き家の維持管理をあまり意識していない様子が伺え る。回答された 9 事例に限定されるものの、その具体的な内容につ いては、住宅外部の点検、雨漏りの点検と補修、床下の改築であっ た。空き家の維持管理の課題は、地域住民と程々の親密関係を築い ていくことであり、住宅の劣化を防ぐだけではなく、ストックの活 用、地域活性化につながる維持管理であるべきだと考えられている。 地域住民との関係について、親密な関係が求められる一方で、成果 ばかりを求められて負担に感じている工務店もあり、程よい関係の 構築が、継承のためには重要であるといえる。

空き家の維持管理の今後の取り組みについて、「取り組みあり」は 半数以上が取り組んでいきたいと回答しているものの、取り組みな し」においては、取り組みたくないが約 6 割を占めた。その理由と して、手続きへの負担感、経済的な負担感が強い。空き家の増加に

\section{表 15 空き家の維持管理の取り組み}

\begin{tabular}{|c|c|c|}
\hline 空き家の維持管理 & 回答数 & \\
\hline 取り組みあり & 9 & \\
\hline 取り組みなし & 50 & \\
\hline 空き家の維持管理に & 取り組みあり & 取り組みなし \\
\hline 対する今後の希望 & $\%(n=9)$ & $\%(n=50)$ \\
\hline 取り組んでいきたい & 55.6 & 34.8 \\
\hline 取り組みたくない & 0.0 & 58.7 \\
\hline
\end{tabular}


伴う空き家の維持管理に関する取り組みは、重要になってくると予 想されるものの、住宅に関わる専門家としての工務店が、積極的に 関わりにくい現状があることがわかった。空き家の維持管理の必要 性を感じないとの意見もあった。所有者の意向や建物の状態にも大 きく影響されるものの、建物の状態を正確に把握し、地域環境に応 じた維持管理を進めていく専門家として工務店の役割にその可能性 を期待していたが、現状は厳しいことが明らかとなった。地域住民 との関係の持ち方にも課題がみられたように、空き家の所有者、地 域住民、そして工務店の三者が、空き家をどのようにしていきたい か、空き家を含む地域をどうしていくべきなのかを考え、それぞれ の協力、協働が必要であり、それにより地域に即した空き家の管理 が実践され、空き家の活用につながっていくのであろう。

\section{（８）伝統的木造住宅の維持管理における共助のあり方}

まちづくり団体（地域の特性を活かし魅力を高めるまちづくり活 動を主体的に行う団体）と関わりのある工務店は 2 割程度であった が、その多くは地元 NP0 法人などとの関わりを持ち、建築に関する 専門家としてまちづくりや町並み保存に関わっていることがわかっ た。また、関わりのない工務店において、今後「関わりを持ちたい」 $52.1 \%$ 、「関わりたくない」 $41.7 \%$ と意見が分かれていた。関わりた い理由は個人の充実のためが高く、ついで、地域活性や業の充実で あった。関わりたくない理由は時間・人手不足であった。

また、建築士や大工としての生業とは別に、個人的にボランティ アで建物調查や空き家の維持管理、伝統的木造住宅の改修工事に関 わったことのある回答者は1割にも満たずわずかであった(表 16)。 経験者は少なかったが、専門家としての知識や技術は、今後、地域 で住宅の維持管理をサポートしていく上で必要とされていくと予想 され、ボランティアとしての活躍も期待される。なお、関わったこ とがない回答者において、今後の希望をみると、「したくない」3〜4 割、「やってみたい」 2 割前後であった。消極的な意見がやや優勢で あるものの、機会があればボランティアとして、自身の専門性を活 かしていきたいと考えている回答者もあり、比較的年齢の若い回答 者に多い傾向がみられた。熟年以上の場合、ボランティアなどとし ての関わりについて、自身の高齢化による体力の低下を危惧してい ること、若年者では協力したい意識はあるものの、技術不足や経験 不足を不安視する傾向がみられた。回答者の多くが、体力または技 術、経験面で不安を持っていることが明らかとなった。

また、町並み保全のための伝統的木造住宅の維持保全や改修工事 において、専門的技術を有さない一般の人が関わることについて(表 17)、「関わって欲しい」、関わって欲しくない」、「条件による」と 意見が分かれた。関わって欲しい理由は、関わりたいという気持ち を尊重するもので、地域住民を含め、専門性の有無ではなく、町に 関わる人々の協力が必要であると考えられているためと思われる。

一方、関わって欲しくない理由は、技術面への不安が大きく、危険 性を感じている回答者もいる。条件として、関われる内容を明確に しておく、訓練の程度を考慮するが挙げられていることから、関わ りたいという気持ちと技術の実態を把握して、バランスよく活かし ていくことが必要であるといえる。

さらに、伝統的木造住宅の維持管理・維持保全において、住宅が 立地する地域の特性や住まい方について、考慮すべき・考慮したい
との意見は強く、伝統的木造住宅は地域特性のもとに存在し、使い 続けられてきた住宅との認識が高い。地域の特性として具体的に挙 げられたのは、周囲の環境や景観、地産地消による材料の循環利用、 高齢者が元気な町、若者が住みや寸い町であり、単に物理的な気象 状況や地理的な状況だけではなく、居住者が生き生きと暮らせる地 域である。また、維持管理に大きく影響すると考えられる住まい方 について、住む人のニーズに合わせる、住み心地が良い、時代に合 った住まい方が必要であると考えられている。つまり、伝統的木造 住宅の継承において、居住者（使用者）が生活していることが重要 で、現在の生活要求に応じながら、居住者が主体となって住宅の維 持管理を行っていく、行っていけることが必要であると考えられて いることが明らかとなった。

このように、伝統的木造住宅の維持管理において、住宅のハード 面から維持管理に関わる立場の専門家として、また、居住者による 維持管理を支える専門家として、居住者の生活に重点をおいた維持 管理の重要性を意識している工務店があることが明らかとなった。

表 16 ボランティアとしての伝統的木造住宅の維持保全や継承に 関わることについて

\begin{tabular}{|c|c|c|c|c|c|}
\hline \multicolumn{2}{|c|}{ ボランティアとしての実績 } & \multicolumn{2}{|c|}{ 回答数 \% $(n=64)$} & 今後の希望 & \multirow{2}{*}{$\frac{\text { 回答数 }}{3}$} \\
\hline 建物調査 & あり & 5 & 7.8 & $\rightarrow$ 継続したい & \\
\hline & なし & 57 & 89.1 ال & したくない & 0 \\
\hline & & & & マやってみたい & 14 \\
\hline & & & & したくない & 19 \\
\hline \multirow[t]{4}{*}{ 空き家の維持管理 } & あり & 3 & 4.7 & $\rightarrow$ 継続したい & 1 \\
\hline & なし & 59 & 92.2 & したくない & 0 \\
\hline & & & & マやってみたい & 15 \\
\hline & & & & したくない & 22 \\
\hline 伝統的木造住宅の & あり & 2 & $3.1-$ & $\rightarrow$ やってみたい & 1 \\
\hline \multirow[t]{3}{*}{ 改修工事 } & なし & 60 & 93.8 & (体調による) & \\
\hline & & & & マやってみたい & 11 \\
\hline & & & & したくない & 21 \\
\hline
\end{tabular}

\section{表 17 町並み保全のための伝統的木造住宅の維持保全や改修工事 への一般の人の関わりについて}

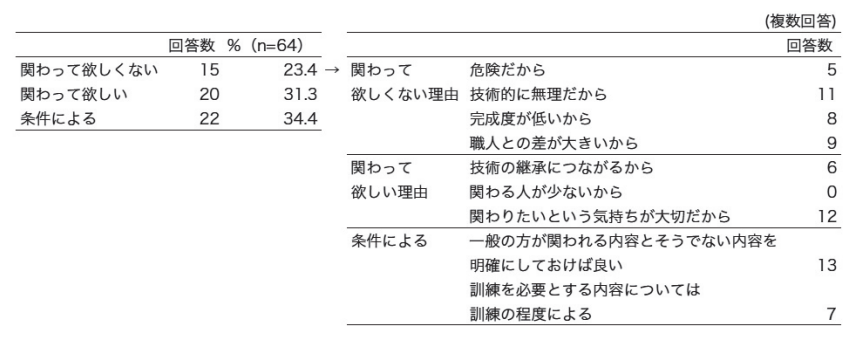

\section{4. まとめ}

伝統的な木造住宅が維持管理され、その地域で町並みを形成する 地域資源として継承されていくためには、所有者の管理だけではな く、地域の人々や専門的技術を有する各種職人、さらには公的なサ ポートなどの協同が必要であると考えられる。その可能性やあり方 を探ることを本研究の目的としている。本報では、伝統的な木造住 宅の維持管理において、専門的技術を有する大工や職人などの存在 が大きかったと考えられることから、居住者による維持管理をサポ 一トするつくり手側の専門家として、県内の建設業や大工業に関わ っている業者を対象として、伝統的木造住宅および町並夕保全につ いてのアンケート調查を実施した。その結果、伝統的な木造住宅を 維持保全していくためには、技術者の養成とともに材料確保、補助 金制度のあり方、見積もりの難しさへの考慮、住民の意識向上とそ 
れを支える地域支援や教育の充実が求められている。地域特性をも つ伝統的な木造住宅は、気象状況や地理的な地域特性のみならず、 地域の景観と調和しつつ、居住者のニーズに対応しながら継承して いくべきであると考えられている。また、居住者の生活を重視しつ つ、居住者と地域住民と専門家や各種職人との協同とともに進めら れていくことが重要であると考えられている。さらに、伝統的木造 住宅の維持管理における工務店による共助について、工務店側もそ の必要性を認識し、関わっていく意識を持っている工務店があり、 居住者の現在の生活に重点をおいた維持管理の重要性、および居住 者の管理意識を支える専門家としての役割が意識されていることが 明らかとなった。今後、伝統的木造住宅の維持管理において、住宅 の安全性や耐久性などの物理的な側面だけではなく、居住者にとっ て住み心地の良い、現代の生活スタイルに合った住まい方を取り入 れながら、居住者と工務店による協同や連携が必要であり、さらに 地域住民も含めた共助が求められていくと考えられる。

\section{謝辞}

本研究を進めるにあたり、アンケート調查にご協力いただきまし た、工務店各社に深謝致します。本研究は文部科学省科学研究補助 金基盤 ( C )「伝統的木造住宅の維持管理における自助、共助、公助 のあり方」による研究成果の一部である。

\section{参考文献}

1) 㱜田洋子, 古本正美, 西本孝一 : 住宅の損傷と維持管理（第 1 報）在 来木造住宅の場合, 木材学会誌, Vol. 35、No. 2, pp. 90 99, 1989, 2

2 ）㱜田洋子, 谷口美幸 : 住宅の損傷と維持管理（第 2 報） 伝統工法木造 住宅の場合, 木材学会誌, Vol. 38、No. 9, pp. 869 875, 1992, 9
3）疋田洋子: 住宅の損傷と維持管理（第 3 報） 秋田県の木造住宅の場合, 木材学会誌, Vol. 39、No. 8, pp. 944 950, 1993, 8

4 ）藤平眞紀子：既存戸建て住宅の維持管理と住宅の耐久性 - 居住者の高 齢化が進行しつつある郊外の住宅地における-, 日本家政学会誌, Vol. 63 No. 7, pp. 399 411, 2012, 7

5 ）野城智也, 安藤正雄, 蟹沢宏剛, 小野宗良, 花山佳子 : 木造住宅の生産 組織に関する研究 その 36 住まい手側からみた住宅の維持保全にお ける専門工事業者との連関，佐倉市住民へのアンケート調査より，日本 建築学会大会学術講演梗概集 F, pp. 523 524, 1989, 10

6) 森 正志, 角倉英明 : 戸建て木造住宅の「つくり手」による維持管理へ の取組みについて，日本建築学会大会学術講演梗概集 F-1, pp. 1127〜 1128, 2010, 9

7 ) 山崎古都子：住居の社会的管理に向けて，都市文化社，1998

8 ）角倉英明: 地域工務店による木造住宅のメンテナンスサービスの展開に 関する考察, 総合論文誌, No. 9, pp. 91〜 96, 2011, 1

9 ) 藤平眞紀子, 村田順子, 田中智子: 伝統的木造住宅における維持管理の変 遷と今後の継承 一ヒアリング調査による維持管理の実態把握と今後の 課題-, 日本家政学会誌, Vol. 66、No. 6, pp. 272 283, 2015, 6

10）前田奈実, 増井正哉：伝統的町家の維持管理システムに関する研究-奈 良県下 3 地区の調査から-, 日本建築学会大会学術講演梗概集 F-1, pp. 225 226, 2003, 9

11）宗田好史：町家再生の論理, 学芸出版社, 2009

12）橋本清勇, 東樋口 護, 宗田好史: 京都市都心部における伝統的木造建物 の維持管理システムの衰退, 日本建築学会計画系論文集, 第 554 号, pp. $259 \sim 265,2002,4$

13）長谷川 徹 : 歴史的市街地における住宅改善に関する研究 - 大工職人 の役割-, 日本建築学会大会学術講演梗概集 F, pp. 51〜 52, 1994, 9

14）水野雅男：金沢市中心部における歷史的木造住宅の保全・継承システム に関する研究 -家族類型と出入り大工との関係性からの考察-, 日本建 築学会計画系論文集, 第 707 号, pp. 157 165, 2015, 1

15）(財) 国土開発技術研究センター建築物耐久性向上技術普及員会: 木造建 築物の耐久性向上技術, 技報堂出版, 1986

16）平成 25 年度住宅・土地統計調査 


\section{A STUDY ON COOPERATION OF BUILDING CONTRACTORS IN THE MAINTENANCE OF TRADITIONAL WOODEN HOUSES}

Based on a questionnaire survey among building contractors

Makiko FUJIHIRA*

* Assoc. Prof., Nara Women's University, Ph.D.

Maintenance performed by house owners is not itself sufficient to ensure that traditional wooden houses are maintained and will be preserved as community resources that define local streetscapes; rather, collaboration with the local community, tradesmen with specialist technical expertise in a variety of fields, and public support are also considered necessary. This study examined both potential and ideal approaches for such community-based initiatives. Given that "regular carpenters" play a dominant role in the maintenance of traditional wooden houses, we conducted a questionnaire survey on traditional wooden houses and streetscape preservation among contractors engaged in building and carpentry within Nara Prefecture. The contractors were manufacturing and fabrication specialists that support the maintenance efforts of house occupants.

The survey results showed that training technical experts and securing appropriate materials are necessary in order to maintain and preserve traditional wooden houses. In addition, it is necessary to carefully consider the effectiveness of subsidy schemes and the difficulty associated with producing work estimates, promote awareness among local residents, and provide community support and education in order to support these efforts. There is widespread acceptance that traditional wooden houses with their traditional character must be preserved in order to maintain harmony with local landscapes, but also that these houses need to meet the requirements of the house occupants. Specifically, these efforts need to be pursued as collaborative initiatives between the occupants, local residents, specialists, and various tradesmen, with an emphasis on the quality of life of the house occupants. The survey also clearly showed that building contractors recognize that they need to collaborate in the maintenance of traditional wooden houses and also that they are willing to be involved in the effort. 